\title{
ANALISIS PRIORITASI PEMILIHAN KOMODITAS DAN LOKASI SENTRA PENGEMBANGAN INDUSTRI PENGOLAHAN PERIKANAN DI KAWASAN TIMUR INDONESIA
}

\author{
Tajerin, Manadiyanto dan Sapto Adi Pranowo")
}

\begin{abstract}
ABSTRAK
Penelitian ini bertujuan untuk mengkaji prioritasi pemilihan komoditas dan lokasi sentra pengembangan industri pengolahan perikanan di Kawasan Timur Indonesia dengan pendekatan metode perbandingan eksponensial. Penelitian dilakukan sejak bulan Januari hingga Desember 2003. Data diperoleh dari hasil wawancara dengan responden yang dianggap ahli. Hasil analisis menunjukkan bahwa pengembangan industri pengolahan perikanan di kawasan timur Indonesia dapat dilakukan dengan memberikan prioritas utama pada pemanfaatan jenis komoditas ikan cakalang sebagai bahan baku dan dengan menggunakan prioritas lokasi sentra pengembangannya di Kota Bitung.
\end{abstract}

\begin{abstract}
An analysis of commodities and site selection priorities for developing fish processing industry in Eastem Indonesia. By: Tajerin, Manadiyanto and Sapto Adi Pranowo

Research aimed to analyze commodities and site selection priorities for developing fish processing Industry in Eastern Indonesian using exponential comparison method was conducted during January to December 2003. Data were obtained from interviewing with expert respondents. The results showed that fisheries processing industry development in Eastern Indonesia skipjack was selected as priority commodity, and Bitung was selected as centre site for development.
\end{abstract}

\section{KEYWORDS: fish processing industry, commodities and site selection}

\section{PENDAHULUAN}

Pembangunan perikanan Indonesia secara berkelanjutan dalam jangka menengah dan panjang bertujuan untuk meningkatkan pertumbuhan ekonomi, mengurangi pengangguran dan meningkatkan kesejahteraan. Ketiga tujuan tersebut dicapai melalui tigàupaya pokok, yaitu mempertahankan kelestarian sumberdaya alam (resource sustainability), meningkatkan pendapatan nelayan dan pembudidaya ikan (termasuk industri yang menangani komoditas ikan) dan menghasilkan pemasukan devisa bagi negara (Simanjuntak, 2001).

Salah satu strategi yang tepat dalam mendukung akselerasi pembangunan perikanan Indonesia yang berkelanjutan adalah melalui pengembangan industri pengolahan produk perikanan karena dapat memanfaatkan sumberdaya ikan secara lebih efisien sejak ikan ditangkap hingga ikan tersebut dikonsumsi dengan cara menjaga kesegaran, mengurangi limbah dan susut hasil dan meningkatkan nilai tambah serta berpeluang untuk menghasilkan devisa yang besar melalui kegiatan ekspornya (Heruwati, 2003; Takashima, 1995). Pengembangan industri pengolahan perikanan sangat relevan dengan konsep pembangunan perikanan berkelanjutan. Pada prinsipnya pembangunan berkelanjutan merupakan konsep fundamental dalam mempertahankan kelestaraian sumberdaya alam hayati yang terbatas ketersediaannya.

Industri pengolahan perikanan merupakan bagian dalam agroindustri yang dilakukan melalui kegiatan pemanfaatan hasil perikanan sebagai bahan baku, mengolah, merancang dan menyediakan peralatan serta jasa dalam meningkatkan nilai tambah secara nyata melalui cara-cara mempertahankan mutu, menghambat atau menghentikan aktivitas mikroorganisme pembusuk, menyelamatkan hasil tangkapan yang melimpah dan memenuhi selera konsumen (Darwis et al., 1983).

Pengembangan industri pengolahan perikanan di Kawasan Timur Indonesia (KTI) berpotensi meningkatkan pertumbuhan ekonomi daerah, meningkatkan penyerapan tenaga kerja dan meningkatkan kesejahteraan masyarakat di kawasan tersebut. Hal ini, karena KTI yang meliputi Kalimantan, Sulawesi, Maluku, Papua dan Nusa Tenggara merupakan wilayah yang memiliki potensi perikanan yang cukup besar khususnya untuk perikanan laut.

*) Peneliti pada Balai Besar Riset Sosial Ekonomi Kelautan dan Perikanan 
Namun sumbangan sub sektor perikanan tersebut terhadap pendapatan daerah di KTI masih rendah bila dibandingkan dengan potensi sumberdaya yang tersedia, yaitu baru mencapai rata-rata sebesar $34 \%$ (Manurung, 1997; Sarjono et al., 1994). Dalam rangka memperkuat posisi dan peran sub sektor perikanan dalam pembangunan $\mathrm{KTI}$, optimalisasi pemanfaatan potensi sumberdaya perikanan laut masih perlu diupayakan. Untuk menunjang tujuan tersebut, pembangunan perikanan laut di KTI akan efektif bila diarahkan pada upaya peningkatan produksi melalui pengembangan sentra industri pengolahan perikanan laut dengan memberi prioritas utama pada komoditi perikanan potensial daerah dan lokasi sentra pengembangannya.

Dari latar belakang dan permasalahan di atas, dipandang penting untuk dilakukan penelitian yang bertujuan untuk menentukan prioritas komoditas ikan unggulan strategis dan lokasi sentra pengembangan industri perikanan di KTI. Hasil penelitian ini diharapkan dapat memberi masukan bagi kebijakan pengembangan perikanan dan peranannya dalam pertumbuhan ekonomi dan kesejahteraan masyarakat di KTI. Selain itu dapat pula menjadi bahan informasi bagi para investor yang ingin mengembangkan usaha perikanan di KTI.

\section{METODE}

\section{Metode Analisis}

Dalam penelitian ini, penentuan jenis komoditas dan lokasi sentra pengembangan industri perikanan di KTI dilakukan dengan menggunakan "Metode Perbandingan Eksponensial" (MPE). Metode MPE ini merupakan salah satu metode untuk menentukan urutan prioritas alternatif berdasarkan penilaian kualitatif dari subyektifitas pengambil keputusan dengan kriteria majemuk (Marimin, 2004). Metode ini digunakan untuk membantu pihak pengambil keputusan untuk menggunakan rancang bangun model yang telah terdefenisi dengan baik.

Dalam menggunakan metode MPE terdapat beberapa tahapan yang harus dilakukan, yaitu (Marimin, 2004; Manning, 1984): (1) Menentukan tingkat kepentingan relatif dari setiap kriteria keputusan atau pertimbangan kriteria dengan menentukan skala konvensi perbandingan (parwaise comparison); (2) Melakukan penilaian terhadap semua alternatif pada setiap kriteria; (3) Menghitung skor atau nilai total pada setiap alternatif dan (4) Membuat urutan skala prioritas keputusan berdasarkan skor atau nilai total masing-masing alternatif dengan cara mengurutkan skor atau nilai total alternatif terbesar sampai skor atau nilai total terkecil.
Formulasi perhitungan skor atau total nilai untuk setiap alternatif dalam MPE adalah sebagai berikut:

$$
T N_{i}=\sum_{j=1}^{m}\left(R k_{i j}\right)^{T K K_{j}}
$$

\section{dimana}

$$
\begin{aligned}
T N_{j}= & \text { total nilai atau skor alternatif ke-i } \\
R k_{i j}= & \text { derajat kepentingan relatif kriteria ke-jpada } \\
& \text { pilinan keputusan- } i \\
T K K_{j}= & \text { tingkat kepentingan kriteria keputusan } \\
& \text { ke- } j ; T K K_{i j}>0, \text { bulat. } \\
m= & \text { jumlah kriteria keputusan }
\end{aligned}
$$

Penentuan tingkat kepentingan kriteria dilakukan melalui cara wawancara dengan responden yang dianggap ahli (expert). Sedangkan penentuan skor alternatif pada kriteria tertentu dilakukan dengan memberi nilai setiap alternatif berdasarkan nilai kriterianya. Semakin besar nilai alternatif semakin besar pula skor alternatif tersebut. Total skor masingmasing alternatif keputusan akan relatif berbeda secara nyata karena adanya fungsi eksponensial. Secara statistik, MPE mempunyai keuntungan dalam mengurangi bias yang mungkin terjadi dalam analisis. Nilai skor yang besar dalam menggambarkan urutan prioritas yang menjadi besar (fungsi eksponensial) ini mengakibatkan urutan prioritas alternatif keputusan menjadi lebih nyata (Sujarto, 1987; Marimin, 2004).

Perbandingan antar kriteria keputusan dalam MPE untuk menentukan jenis komoditas dan lokasi sentra pengembangan industri pengolahan perikanan dilakukan melalui dua tahap perbandingan yaitu: (1) perbandingan antara kriteria dalam penilaian tingkat kepentingan dan (2) perbandingan antar kriteria dalam pemeringkatan altematif berdasarkan kelompok kriteria keputusan. Pengolahan data berdasarkan metode MPE di atas, seluruhnya dilakukan dengan menggunakan Software Agroplanvest 1.1 (Sutiyono, 2000). Pengolahan data berdasarkan MPE dengan menggunakan Software tersebut untuk penelitian sejenis telah dilakukan oleh beberapa peneliti, seperti Sutiyono (2002) untuk kajian industri sayuran segar; Muspitawati (2002) untuk kajian strategi peningkatan kualitas produk sayuran segar dan Ma'arif (1993) dan Marimin \& Sutiyono (2002) untuk kajian perencanaan investasi produk agroindustri.

\section{Pemilihan Responden dan Pengumpulan data}

Pemilihan responden dilakukan secara sengaja (purposive) terhadap mereka yang dianggap ahli (expert) atau memiliki informasi dan menguasai permasalahan sesuai dengan topik yang dikaji dan 
mereka yang terkait atau memiliki kompetensi dengan tujuan ingin diperoleh dari penelitian ini. Responden tersebut dalam hal ini terdiri dari tokoh dari nelayan, Asosiasi Pengalengan Ikan (API), Asosiasi Tuna Indonesia (ASTUIN), Himpunan Nelayan Seluruh Indonesia (HNSI) di tiga daerah pengamatan (Kota Bitung Propinsi Sulawesi Utara, Kota Ternate Propinsi Maluku Utara dan Kota Sorong Propinsi Papua), perusahaan pengalengan ikan, birokrat, peneliti dan akademisi.

Data yang dikumpulkan berupa data primer yang diperoleh langsung melalui wawancara dengan menggunakan daftar pertanyaan, sedangkan data sekunder diperoleh dari instansi terkait dengan penelitian yang dilakukan, seperti Dinas Kelautan dan Perikanan, Dinas Perindustrian dan Perdagangan dan instansi perusahaan terkait.

\section{Lokasi dan Waktu Penelitian}

Penelitian dilakukan di daerah-daerah di KTI yang diwakili oleh Kota Bitung, Kota Ternate dan Kabupaten Sorong sejak bulan Januari hingga Desember 2003.

\section{HASIL DAN BAHASAN}

\section{Kinerja Industri Perikanan}

Ikan tuna dan cakalang merupakan komoditas dominan yang dihasilkan dari perikanan tangkap di $\mathrm{KTI}$ yang menyumbang dalam perolehan devisa negara tidak kurang dari $12,4 \%$ dalam kurun waktu 11 tahun terakhir, yaitu sejak 1990-2001. Agar dapat memberikan nilai tambah secara nyata, pengembangan industri pengolahan perikanan tuna dan cakalang membutuhkan penanganan yang tepat dan kerjasama integral antara nelayan, swasta dan pemerintah. Namun dalam perkembangannya, industri pengolahan perikanan tuna dan cakalang masih menghadapi banyak permasalahan yang harus ditangani secara serius dan berwawasan ke depan. Beberapa permasalahan yang perlu dicermati dalam pengembangan industri pengolahan produk perikanan di KTI dapat diuraikan pada penjelasan berikut.

\section{Masalah Sistem Kelembagaan dan Model Pengusahaan}

Permasalahan dalam sistem kelembagaan dan model pengusahaan yang belum sempurna pada industri pengolahan perikanan tuna dan cakalang di KTI dicirikan dengan adanya: (1) pembagian keuntungan yang belum adil terutama bagi nelayan penangkap dibanding dengan yang diterima oleh mata rantai tuna dan cakalang lainnya; (2) rantai penanganan bahan baku yang panjang, misalnya ulah para pengusaha pelabuhan dan pelayanan TPI yang didominasi pihak-pihak tertentu (praktek monopoli terselubung; (3) manajemen kelembagaan dan pola pengusahaan yang kurang efisien dan efektif dan (4) kurangnya koordinasi antar kelembagaan; dan infrastruktur yang belum memadai (Azis, 2003; Hartarto, 1993; Toding, 1997).

Penggunaan kapal-kapal penangkap ikan asing juga merupakan masalah dalam pola pengusahaan agroindutri tuna dan cakalang, di mana negosisasi penggunaan kapal (sistem carter) masih merugikan pihak Indonesia. Sebagai contoh pendaratan ikan di pelabuhan yang ditunjuk oleh pemerintah dan penggunaan anak buah kapal (ABK) berkewarganegaraan Indonesia masih tidak sesuai dengan ketentuan (kurang dari 30\%). Dampak dari masalah penggunaan kapal penangkap ikan asing dan kurangnya koordinasi antar kelembagaan menimbulkan masalah baru, khususnya bagi industri pengolahan hasil perikanan di KTI, yaitu jumlah bahan baku yang tidak memenuhi kapasitas produksi pabrik pengolahan dan kurangnya kontinuitas bahan baku bagi kelancaran produksi pabrik tersebut.

\section{Masalah Kualitas Ikan}

Kualitas ikan tuna dan cakalang merupakan hal yang sangat penting dalam agroindustri pengolahan perikanan tuna dan cakalang di KTI, namun kesadaran terhadap pentingnya kualitas (mutu) masih rendah. Di samping permasalahan tersebut, terdapat masalah lain terkait dengan masalah kualitas ikan yaitu teknologi penyimpanan dan pengolahan ikan tuna dan cakalang yang kurang maju, rantai pemasaran yang panjang yang akan menurunkan mutu; dan standar kualitas yang belum sesuai dengan standar internasional (HACCP oleh Amerika Serikat, QME oleh Kanada, dan ISO 9000 oleh Eropa) (Putro, 2003; Heruwati, 2003).

\section{Masalah Dukungan Permodalan}

Masalah permodalan merupakan masalai: yang vital, sebab permodalan menyangkut segi pendanaan untuk pengusahaan industri pengolahan perikanan. Dalam pengusahaan agroindustri pengolahan produk perikanan ikan tuna dan cakalang di KTI, masalah permodalan ini timbul karena suku bunga yang tidak kompetitif dan sulitnya memperoleh pinjaman dari lembaga keuangan (perbankan) (Aziz, 2003).

Tidak adanya kredit untuk bidang perikanan yang diberikan lembaga perbankan disebabkan beberapa hal, antara lain: (a) industri perikanan masih dianggap sebagai industri yang penuh resiko, (b) pemasaran yang tidak terjamin, (c) sulit monitoring, (d) pemasaran luar negeri sering terkendala (Dinau, 2003). Untuk mengatasi hal tersebut seyogyanya ada bank khusus 
yang membiayai usaha perikanan dengan membuat jaringan di sentra-sentra produksi perikanan, membentuk skim-skim khusus perikanan, mempromosikan usaha perikanan serta harus ada perlindungan khusus terhadap usaha perikanan agar investor merasa aman.

\section{Masalah Pemasaran}

Masalah pemasaran produk olahan ikan tuna dan cakalang Indonesia di pasar Internasional antara lain disebabkan oleh adanya pergeseran peta politik global dan ekonomi global serta terbentuknya blok-blok perdagangan. Hal ini mengakibatkan adanya pembatasan kuota ekspor komoditas tuna dan cakalang dan persyaratan yang ketat oleh negaranegara importir, seperti pemberlakuan penahanan otomatis (automatic detention) dan pengecekan langsung oleh tim ahli dari negara-negara importir Eropa (Putro, 2003; Tim Samudra, 2005).

Masalah pemasaran yang lain adalah informasi pasar tuna dan cakalang yang tidak akurat serta harga tuna dan cakalang yang mengikuti fluktuasi kondisi perekonomian Jepang dan pasaran Internasional di luar Jepang. Kebijakan dari pihak luar negeri seperti WTPO (Word Tuna Pursein Organization), sebuah asosiasi pengusaha ikan dunia yang memproteksi harga ikan tuna cakalang yang datang dari negaranegara Asia termasuk Indonesia. Tampaknya upaya proteksi tersebut dilatarbelakangi oleh sentimen negatif dari WTPO terhadap negara Asia termasuk Indonesia untuk menekan harga ikan tuna cakalang dari US $\$ 900$-US $\$ 1000$ per metrik ton menjadi US $\$ 450-U S \$ 500$ per metrik ton bahkan pernah jatuh ke harga US $\$ 300$ per metrik ton. Harga tersebut sudah berlangsung sejak lima tahun terakhir. Di samping itu ada juga kebijakan dari pemerintah Amerika Serikat yang mengenakan pungutan $12 \%$ hingga $24 \%$ per dos ikan kaleng (Media Indonesia, 2003).

Dari dalam negeri sendiri, adanya kecenderungan beban fiskal yang menghambat peningkatan daya saing industri pengolahan perikanan di KTI. Adanya beban fiskal yang memberatkan usaha pada industri pengolahan produk perikanan yang dipungut Pajak Pertambahan Nilai (PPN) sebesar $15 \%$, sementara pada saat yang sama pajak impor ikan kaleng hanya $5 \%$. Perbedaan pungutan yang cukup signifikan ini

Tabel 1. Hasil rataan pendapat responden pada perbandingan kriteria untuk pemilihan komoditi dalam pengembangan industri perikanan di Kawasan Timur Indonesia, 2003

Table 1. Average of respondent's opinion on comparative criteria for commodity and site selection for developing fish processing industry, 2003

\begin{tabular}{|c|c|c|c|}
\hline No & Krite ria/Criterias & $\begin{array}{l}\text { Rata an bobot/ } \\
\text { Average of weights }\end{array}$ & $\begin{array}{l}\text { Prioritas/ } \\
\text { Priorities }\end{array}$ \\
\hline 1 & Ketersediaan bahan baku/Availability raw matterials & 0,094 & 6 \\
\hline 2 & Ketersediaan tenaga kerja/Availability labors & 0,104 & 5 \\
\hline 3 & Potensi pasar komoditi atau olahannya/Market potentials & 0,183 & 2 \\
\hline 4 & $\begin{array}{l}\text { Keragaman bentuk olahannya/Diversity of fish } \\
\text { processing product }\end{array}$ & 0,050 & 9 \\
\hline 5 & $\begin{array}{l}\text { Kemudahaan penanganan pasca penen/Ease of post } \\
\text { harvest }\end{array}$ & 0,053 & 8 \\
\hline 6 & $\begin{array}{l}\text { Ketersediaan sarana penangkapan/produksi/ } \\
\text { Availability of input production }\end{array}$ & 0,194 & 1 \\
\hline 7 & Biaya penangkapan/Cost of fishing & 0,123 & 4 \\
\hline 8 & $\begin{array}{l}\text { Dukungan kebijakan pemerintah/Government policy } \\
\text { support }\end{array}$ & 0,084 & 7 \\
\hline 9 & Tingkat keuntungan/Leve/ of profit & 0,165 & 3 \\
\hline
\end{tabular}

Sumber/Source: Hasil pengolahan data primer menggunakan metode perbandingan eksponensial/Result of primary data processing by using the exponential comparison method 
dapat menyebabkan produk yang dihasilkan dari industri pengolahan perikanan menjadi tidak kompetitif (Wawa, 2003).

\section{Pilihan Komoditi Potensial}

Komoditi potensial daerah adalah komoditi yang mempunyai nilai ekonomis dan cukup tersedia dibandingkan yang lainnya serta dapat dikembangkan untuk menunjang pembangunan daerah tersebut (Darwis et al., 1983). Komoditi potensial dapat dilihat baik dari kriteria-kriteria aspek kualitas maupun kuantitas. Secara rinci penilaian responden terhadap kriteria-kriteria yang berpengaruh terhadap pemilihan komoditas dalam pengembangan industri pengolahan perikanan di KTI disajikan pada Tabel 1.

Tabel 1 (Rataan Nilai dari Lampiran 1) menunjukkan bahwa dari hasil pembobotan dan penetapan prioritas, terdapat tiga kriteria utama yang harus diperhatikan dalam pemilihan komoditi yang akan dikembangkan sebagai bahan baku dalam industri perikanan di KTI. Ketiga kriteria utama tersebut adalah: (1) ketersediaan saran penangkapan/produksi dengan rataan bobot sebesar 0,194 sebagai prioritas pertama; (2) potensipasar komoditi atau olahannya dengan rataan bobot sebesar 0,183 sebagai pioritas kedua; (3) tingkat keuntungan dengan rataan bobot sebesar 0,165 sebagai prioritas ketiga dan (4) biaya penangkapan/budidaya dengan rataan bobot sebesar 0,123 .

Dalam perencanaan pengembangan komoditi perikanan di KTI, faktor bahan baku tidak merupakan faktor penghambat karena diperkirakan sumberdaya ikan di perairan KTI masih cukup tersedia. Hal ini didukung dari perkembangan produksi perikanan yang semakin meningkat, seperti untuk kasus ikan cakalang (Tabel 2).

Tangkapan cakalang pada tahun 1990 baru mencapai 114.168 ton, naik mencapai puncak tahun 1997 menjadi 187.206 ton, pada tahun 1998 turun sekitar $50 \%$ menjadi 97.068 ton dan naik lagi tahun 1999 menjadi 244.747 ton, kemudian naik lagi tahun 2001 menjadi 253.050 ton. Dalam kurun waktu satu dekade terjadi kenaikan lebih dua kali lipat. Dari hasil produksi tersebut, sekitar $90 \%$ produksi cakalang dihasilkan oleh KTI yaitu 191.598 ton (Direktorat Jenderal Perikanan Tangkap, 2001).

Dengan demikian faktor bahan baku yang tidak terpilih sebagai faktor utama dapat diterima. Dari hasil

Tabel 2. Produksi ikan cakalang di Indonesia dan Kawasan Timur Indonesia, 1990-2001

Table 2. Skipjack production in Indonesia and Eastern Indonesia, 1990-2001

\begin{tabular}{ccc}
\hline \multirow{2}{*}{$\begin{array}{c}\text { Tahun/ } \\
\text { Years }\end{array}$} & \multicolumn{2}{c}{$\begin{array}{c}\text { Produksi ikan ca kalang (ton)l } \\
\text { Skipjack production (ton) }\end{array}$} \\
\cline { 2 - 3 } & $\begin{array}{c}\text { Indonesial } \\
\text { Indonesian }\end{array}$ & $\begin{array}{c}\text { Kawasan Timur Indonesial } \\
\text { Eastern Indonesian }\end{array}$ \\
\hline 1990 & 114.168 & 105.453 \\
1991 & 132.695 & 110.687 \\
1992 & 152.038 & 132.598 \\
1993 & 121.407 & 90.654 \\
1994 & 157.663 & 143.253 \\
1995 & 159.667 & 132.674 \\
1996 & 182.149 & 167.654 \\
1997 & 187.206 & 167.543 \\
1998 & 97.068 & 70.765 \\
1999 & 244.747 & 219.075 \\
2000 & 236.275 & 206.786 \\
2001 & 253.05 & 191.598 \\
\hline Sumber/Source: & Direktoral jenderal perikanan tangkap, 2001/ \\
& Directorate general of capture fisheries, 2001
\end{tabular}


penetapan bobot dan prioritas pada Tabel 1, yang menjadi faktor utama justru bukan bahan baku tetapi sarana penangkapan/produksi yans memadai untuk mengambil hasil laut lebih banyak dan berkualitas.

Ketersediaan sarana penangkapan yang memadai akan membantu para nelayan meningkatkan kapasitas dan mutu penangkapan. Saat ini sarana penangkapan cakalang di KTI adalah pole and line dengan jumlah yang masih terbatas.
Sampai dengan tahun 2000 jumlah pole and line di KTI sebanyak 1.581 unit dengan berbagai ukuran (Direktoral Jenderal Perikanan Tangkap, 2001).

Alat tangkap pole and line ini merupakan alat tangkap paling selektif dan dapat menjaga mutu hasil tangkapan. Namun karena banyak kapal asing ilegalyang melakukan penangkapan dengan menggunakan purse seine maupun gillnet dengan ukuran besar telah menyebabkan hasil tangkapan pole

Tabel 3. Perbandingan antara kriteria pemilihan dengan alternatif komiditas dalam pemilihan komoditas unggulan di Kawasan Timur Indonesia, 2003

Table 3. Comparation between choice of criteria and commodity altematives in the selection of commodities in Eastern Indonesia, 2003

\begin{tabular}{|c|c|c|c|c|c|c|c|c|c|c|c|c|}
\hline \multirow{2}{*}{$\begin{array}{l}\text { Kriteria pemilihan/ } \\
\text { Criterias of choice }\end{array}$} & \multicolumn{11}{|c|}{ Alternatif komoditi/Commodity alternatives } & \multirow{2}{*}{$\begin{array}{l}\text { Bobot kriterial } \\
\text { Wight of } \\
\text { criterias }\end{array}$} \\
\hline & 1 & II & III & IV & $\mathbf{V}$ & VI & VII & VIII & $\mathbf{I X}$ & $\mathbf{x}$ & $\mathbf{X I}$ & \\
\hline$\overline{\mathrm{KBB}}$ & 9,3 & 6,0 & 4,5 & 5,3 & 2,7 & 3,6 & 5,8 & 5,4 & 5,0 & 3,0 & 3,8 & 0,090 \\
\hline KTK & 8,7 & 4,3 & 3,2 & 1,7 & 3,2 & 3,0 & 2,8 & 4,0 & 2,8 & 3,3 & 3,0 & 0,099 \\
\hline PPK & 9,5 & 6,7 & 4,5 & 4,8 & 4,3 & 2,2 & 3,8 & 4,7 & 2,3 & 4,3 & 4,0 & 0,178 \\
\hline KBO & 8,7 & 6,2 & 3,0 & 4,3 & 4,2 & 3,7 & 4,5 & 5,0 & 3,5 & 3,0 & 3,8 & 0,044 \\
\hline KPP & 7,2 & 4,2 & 4,3 & 5,6 & 5,2 & 2,3 & 1,7 & 2,5 & 1,2 & 1,5 & 3,5 & 0,048 \\
\hline KSP & 7,7 & 4,0 & 2,5 & 1,5 & 1,6 & 1,7 & 3,8 & 3,3 & 2,8 & 2,5 & 2,2 & 0,189 \\
\hline BPB & 6,2 & 2,0 & 2,3 & 1,2 & 2,0 & 3,7 & 3,0 & 4,0 & 2,2 & 3,2 & 2,3 & 0,116 \\
\hline DKP & 9,5 & 6,0 & 5,0 & 5,5 & 4,8 & 3,0 & 3,7 & 5,2 & 4,8 & 4,8 & 5,5 & 0,081 \\
\hline TKU & 8,2 & 6,2 & 5,5 & 6,7 & 5,5 & 3,0 & 3,3 & 4,2 & 1,8 & 2,7 & 3,2 & 0,158 \\
\hline $\begin{array}{l}\text { Nilai total/Totals } \\
\text { value }\end{array}$ & 75 & 45,6 & 34,8 & 34,1 & 33,5 & 26,2 & 32,4 & 38,3 & 26,4 & 28,3 & 29,3 & \\
\hline
\end{tabular}

Sumber/Source: Hasil pengolahan data primer menggunakan metode perbandingan eksponensial/ Result of primery data processing byusing the exponential comparison method

Keterangan/Remaks :

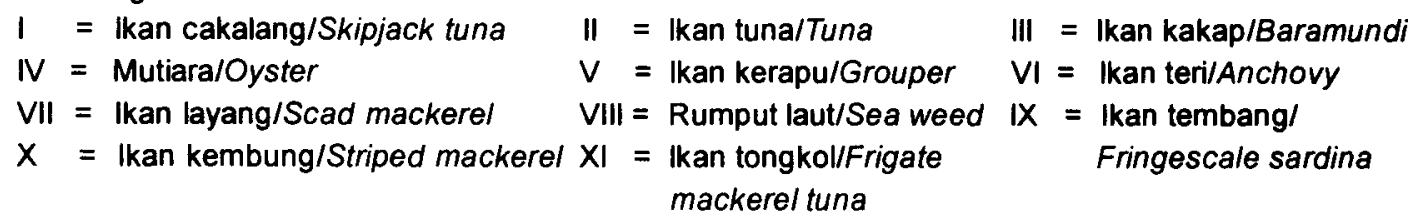

$\mathrm{KBB}=$ Ketersediaan bahan baku/Raw matterials availability

$K T K=$ Ketersediaan tenaga kerja/Labor availability

PPK = Potensi pasar komoditi dan olahannya/Market of commodity and processing

$\mathrm{KBO}=$ Keanekaragaman bentuk olahan $/$ Kind processing diversity

$\mathrm{KPP}=$ Kemudahan penanganan pascapanen/Easy of post harvest handling

$\mathrm{KSP}=$ Ketersediaan sarana produksi/lnput production availability

$\mathrm{BPB}=$ Biaya penangkapan dan budidaya/Cost of fising and culture

DKP = Dukungan kebijakan pemerintah/Goverment policy supporting

TKU $=$ Tingkat keuntungan usaha/Level of farming profit 
and line menjadi berkurang atau tersaingi. Untuk itu sangat diperlukan adanya penegakan hukum (law enforcement) ataupun aturan yang tegas terhadap kapal asing yang melakukan penangkapan secara ilegal, demi menjaga pasokan (supply) atau ketersediaan bahan baku ikan bagi pengembangan industri perikanan di KTI (Simorangkir, 2003).

Faktor pasar sebagai prioritas kedua merupakan faktor yang sangat mendukung upaya pengembangan, mengingat nelayan selalu kesulitan dalam memasarkan hasil tangkapan dengan harga yang menggairahkan, sementara produk perikanan sangat rentan dengan penyimpanan yang cukup lama tanpa perlakukan. Eksploitasi perikanan di $\mathrm{KTI}$ akan berkembang dengan baik, bila ditunjang oleh kelancaran pemasaran untuk kepentingan domestik maupun internasional serta distribusi dari sentra produksi untuk menjamin kelangsungan pasokan produk perikanan (Bailey et al., 1997).

Tingkat keuntungan sebagai prioritas ketiga menunjukkan bahwa dalam pengembangan komoditi potensial di KTI tidak terlepas dari faktor ekonomi atau besarnya keuntungan yang dapat diperoleh dari pengembangan komoditi tersebut. Suatu perusahaanselalu bertujuan untuk mendapatkan keuntungan maksimal dan mengingat tingkat keuntungan sangat berhubungan dengan kemungkinan resiko yang akan dihadapi oleh produsen (Porter, 1993). Keyakinan untuk memperoleh keuntungan yang tinggi dari kegiatan usaha akan meningkatkan motivasi para investor untuk menanamkan modalnya dalam kegiatan industri perikanan laut.

Dari hasil perbandingan kriteria dengan alternatif komoditi pilihan dengan menggunakan MPE seperti tertera pada Tabel 3, yang menunjukkan bahwa komoditi ikan cakalang merupakan komoditi pilihan dalam pengembangan industri pengolahan karena mendapatkan prioritas pertama dengan nilai total tertinggi yaitu sebesar 75,0 . Prioritas selanjutnya secara berturut-turut disusul oleh komoditas ikan tuna $(45,6)$, rumput laut $(38,8)$, ikan kakap $(34,8)$, mutiara $(34,1)$, ikan kerapu $(33,5)$, ikan layang $(32,4)$, ikan tongkol $(29,3)$, ikan kembung $(38,3)$, ikan tembang $(26,4)$ dan ikan teri $(26,2)$.

Terpilihnya ikan cakalang sebagai komoditi yang paling potensial untuk dikembangkan di KTI dinilai cukup beralasan, mengingat produksi komoditi cakalang di KTI yang semakin meningkat (Tabel 2). Untuk kebutuhan ekspor, permintaan komoditi tersebut juga cukup tinggi sehingga prospek pengembangannya cukup luas.

Komoditi ikan cakalang dari segi pengolahannya telah banyak dilakukan baik secara tradisional rumah-

Tabel 4. Rataan pendapat responden pada perbandingan kriteria untuk pemilihan lokasi sentra dalam pengembangan industri perikanan di Kawasan Timur Indonesia, 2003

Table 4. Average respondent's opinion on the comparative crieteria for site selection fish processing industry developping in Eastern Indonesia, 2003

\begin{tabular}{llcc}
\hline No & \multicolumn{1}{c}{$\begin{array}{c}\text { Kriterial } \\
\text { Criterias }\end{array}$} & $\begin{array}{c}\text { Bobot/ } \\
\text { Weight }\end{array}$ & $\begin{array}{c}\text { Prioritas/ } \\
\text { Priorities }\end{array}$ \\
\hline 1 Potensi bahan baku/Raw matterials potential & 0,065 & 5 \\
2 & $\begin{array}{l}\text { Potensi usaha indutri pengolahan/Processing industry } \\
\text { bussines potential }\end{array}$ & 0,183 & 1 \\
3 Potensi pasar komoditas/Commodity market potential & 0,139 & 4 \\
4 Potensi tenaga kerja/Labor potential & 0,059 & 6 \\
5 Potensi transportasi/Transportation potential & 0,040 & 8 \\
6 Dukungan masyarakat setempat/Support from local & 0,046 & 7 \\
$\begin{array}{l}\text { society } \\
7\end{array}$ & 0,149 & 3 \\
$\begin{array}{l}\text { Aksesibilitas ke pusat pertumbuhan/Accesibility to the } \\
8\end{array}$ & $\begin{array}{l}\text { Potensi jaringan informasi/ Potention of information } \\
\text { networking }\end{array}$ & 0,153 & 2 \\
\hline
\end{tabular}

Sumber/Source: Hasil pengolahan data primer menggunakan metode perbandingan eksponensial/ Result of primary data processing by using the exponential comparison method 
Tabel 5. Hasil perhitungan MPE untuk pemilihan lokasi sentra pengembangan industri pengolahan ikan cakalang di Kawasan Timur Indonesia, 2003

Table 5. Result of the MPE method for site selection of the skipjack processing indutry development in Eastern Indonesia, 2003

\begin{tabular}{|c|c|c|c|c|c|}
\hline \multirow[b]{2}{*}{ No } & \multirow[b]{2}{*}{ Kriteria/Criterias } & \multicolumn{3}{|c|}{$\begin{array}{c}\text { Nilai rataan alternatif lokasil } \\
\text { Average values of location alternatives }\end{array}$} & \multirow{2}{*}{$\begin{array}{l}\text { Bobot kriterial } \\
\text { Weight of criterias }\end{array}$} \\
\hline & & $\begin{array}{l}\text { Bitung } \\
\text { (Sulut) }\end{array}$ & $\begin{array}{l}\text { Ternate } \\
\text { (Malut) }\end{array}$ & $\begin{array}{l}\text { Sorong } \\
\text { (Irjabar) }\end{array}$ & \\
\hline 1 & $\begin{array}{l}\text { Potensi bahan baku/Potential } \\
\text { of raw matterial }\end{array}$ & 6,1 & 6,4 & 6,2 & 0,129 \\
\hline 2 & $\begin{array}{l}\text { Potensi usaha industri } \\
\text { pengolahan/Potential of } \\
\text { processing industry bussines }\end{array}$ & 6,7 & 5,0 & 6,0 & 0,173 \\
\hline 3 & $\begin{array}{l}\text { Potensi pasar ikan } \\
\text { cakalang/Potential skipjack } \\
\text { market }\end{array}$ & 6,1 & 5,4 & 5,8 & 0,146 \\
\hline 4 & $\begin{array}{l}\text { Potensi tenaga kerja/Labor } \\
\text { potential }\end{array}$ & 6,3 & 4,6 & 5,7 & 0,058 \\
\hline 5 & $\begin{array}{l}\text { Potensi } \\
\text { transportasi/Transportation } \\
\text { potential }\end{array}$ & 6,7 & 6,1 & 5,5 & 0,148 \\
\hline 6 & $\begin{array}{l}\text { Dukungan masyarakat } \\
\text { setempat/Supporting for local } \\
\text { society }\end{array}$ & 6,6 & 4,8 & 5,9 & 0,049 \\
\hline 7 & $\begin{array}{l}\text { Aksesbilitas ke pusat } \\
\text { pertumbuhan/Accesibility to } \\
\text { central of growth }\end{array}$ & 7,0 & 5,4 & 4,4 & 0,147 \\
\hline \multirow[t]{2}{*}{8} & $\begin{array}{l}\text { Potensi jaringan } \\
\text { informasi/Potention of } \\
\text { information networking }\end{array}$ & 7,4 & 6,0 & 5,0 & 0,154 \\
\hline & Nilai total/Total values & 52,9 & 43,7 & 44,5 & \\
\hline
\end{tabular}

Sumber/Source: Hasil pengolahan data primer menggunakan metode perbandingan eksponensial/ Result of primary data processing by using the exponential comparison method

rumah tangga maupun modern oleh perusahaan pengalengan ikan di KTI. Selain itu ditunjang oleh sumberdaya manusia yang cukup tersedia untuk kebutuhan industri pengolahan tersebut. Secara makro, industri pengolahan cakalang di KTI telah memberikan kontribusi yang cukup besar dalam peningkatan pertumbuhan ekonomi daerah, penyerapan tenaga kerja dan peningkatan pendapatan rumah tangga nelayan (Manurung, 2001).

\section{Pilihan Lokasi Sentra Pengembangan}

Dari hasil perbandingan kriteria pada Tabel 4 diketahui bahwa dalam pengembangan komoditi potensial daerah yang diunggulkan, faktor terpenting yang harus diperhatikan adalah potensi usaha industri pengolahan sebagai faktor utama dengan bobot sebesar 0,183 ; potensi jaringan informasi sebagai faktor kedua dengan bobot sebesar 0,153 ; potensi transportasi sebagai faktor ketiga dengan bobot sebesar 0,148; aksessibilitas ke pusat pertumbuhan sebagai faktor keempat dengan bobot sebesar 0,147 ; dan potensi pasar ikan sebagai faktor kelima dengan bobot sebesar 0,146 . Hasil penetapan bobot dan prioritas terhadap kriteria-kriteria yang mempunyai pengaruh pada pilihan lokasi, secara rinci tertera pada Tabel 4 (Rataan Lampiran 2). 
Dalam pemilihan lokasi pengembangan industri pengolahan perikanan di $\mathrm{KTI}$, kriteria potensi usaha industri pengolahan merupakan faktor penentu utama prioritasi pemilihan lokasi sentra. Adanya peran penting dari kriteria tersebut secara implisit menunjukkan bahwa upaya mendorong kinerja usaha industri pengolahan perikanan berkaitan dengan penentuan lokasi sentra pengembangan merupakan faktor kunci keberhasilan industri tersebut. Dengan perkataan lain, agar rencana penggunaan lokasi sentra tertentu dalam pengembangan industri pengolahan perikanan diperlukan adanya kondisi yang dapat mendorong usaha tersebut ke depan seperti dukungan iklim usaha yang kondusif, keberpihakan lembaga keuangan dan kemudahan-kemudahan berkaitan dengan pelaksanaan kegiatan usaha tersebut.

Di samping itu, terdapat temuan bahwa kriteria potensi jaringan informasi yang oleh para responden dinilai lebih penting dibandingkan kriteria potensi transportasi. Padahal untuk dapat membawa produk ke pasar dalam kondisi yang baik akan sangat tergantung kondisi transportasi yang memadai, mengingat produk hasil perikanan mudah rusak sehingga memerlukan penanganan yang cepat. Dengan transportasi yang baik akan mempermudah pergerakan bahan baku mencapai lokasi pemrosesan atau mempermudah barang-barang mencapai konsumen. Pentingnya kondisi transportasi yang baik di suatu wilayah akan mempengaruhi daya saing dan pertumbuhan ekonomi suatu daerah (Kamaludin, 1987).

Diduga relatif rendahnya kriteria potensi transportasi dibandingkan kriteria potensi jaringan informasi, hal ini menunjukkan bahwa akses untuk memperoleh informasi yang akurat mengenai hal-hal lain yang berkaitan dengan produk yang akan dipasarkan (seperti berapa jumlah permintaan, dimana produk tersebut diminta, berapa kisaran tingkat harga produk yang akan dipasarkan dan bagaimana perkembangan selera konsumen) ternyata dinilai lebih penting daripada kriteria potensi transportasi di atas. Fenomena ini berkaitan dengan adanya perkembangan teknologi informasi yang pesat dan tuntutan kebutuhan memperoleh informasi pasar secara tepat dan cepat.

Untuk pemilihan lokasi sentra pengembangan industri pengolahan perikanan dilakukan berdasarkan hasil perhitungan MPE dengan alternatif lokasi sentra pilihan, yaitu Kota Bitung, Ternate dan Sorong (Tabel 5).

Dari Tabel 5 diketahui bahwa berdasarkan nilai nilai total yang diperoleh maka prioritas pilihan lokasi sentra pengembangan utama adalah Kota Bitung dengan total nilai sebesar 53,0 . Sedangkan Kabupaten
Sorong menduduki prioritas kedua dengan total nilai sebesar 44,5 dan Kota Ternate menduduki prioritas ketiga dengan total nilai sebesar 43,7. Dengan demikian, Kota Bitung diprioritaskan menjadi pilihan lokasi sentra pengembangan yang utama untuk industri pengolahan perikanan di KTI

\section{KESIMPULAN DAN IMPLIKASI KEBIJAKAN}

\section{Kesimpulan}

Pengembangan industri pengolahan perikanan di $\mathrm{KTI}$ dapat dilakukan dengan memberikan prioritas utama jenis komoditas ikan cakalang sebagai bahan baku dengan memberikan prioritas utama Kota Bitung sebagai lokasi sentra pengembangannya. Selain itu, faktor-faktor penting yang dinilai berpengaruh terhadap keberhasilan pengembangan industri tersebut yang terkait dengan prioritas utama komoitas adalah ketersediaan sarana penangkapan, potensi pasar, tingkat keuntungan usaha dan biaya penangkapan ikan. Terkait dengan prioritas utama lokasi sentra pengembangan tersebut, faktor-faktor penting adalah potensi usaha indutri pengolahan, potensi jaringan informasi, potensi transportasi, aksessibilitas ke pusat pertumbuhan dan potensi pasar ikan.

\section{Implikasi Kebijakan}

Dalam hubungannya dengan perencanaan pemanfaatan sumberdaya ikan secara efisien melalui upaya peningkatan nilai tambah dan dengan melibatkan peran pengolahan produk atau komoditas ikan, maka pada tahap awal perencanaan tersebut harus mempertimbangkan informasi yang akurat mengenai komditas apa yang akan dikembangkan dan dimana lokasi proses pengolahannya akan dilakukan. Pemilihan komoditas dan lokasi pengembangan secara benar berdasarkan kriteria-kriteria yang tepat akan memberikan jaminan kepada efektifitas perencanaan pemanfaatan sumberdaya ikan untuk tujuan pembangunan perikanan secara berkelanjutan.

Salah dalam menentukan komoditas ikan sebagai bahan baku utama dalam pengembangan industri pengolahan perikanan akan berdampak besar terhadap kerugian secara ekonomi dan pemborosan dalam pemanfaatan sumberdaya ikan. Demikian juga halnya dengan pemilihan lokasi sentra pengembangan, bila dilakukan tidak secara benar tentunya akan mendorong terjadinya ketidakefisienan sehingga industri pengolahan perikanan yang akan dikembangkan menjadi sulit untuk mencapai tingkat keuntungan sebagaimana yang diharapkan bahkan besar kemungkinan akan menderita kerugian dan dalam jangka panjang dapat mengalami kebangkrutan. Oleh karena itu, pemilihan prioritas 
komoditas ikan dan lokasi sentra pengembangan industri perikanan secara tepat dan benar dalam proses perencanaannya, besar $k \in m u n g k i n a n n n y a$ akan menjadikan industri tersebut akan mengalami keuntungan hingga dapat berjalan secara baik dalam jangka panjang.

Pemilihan penggunaaan bahan baku komoditas ikan cakalang pada industri pengolahan perikanan di KTI dengan lokasi sentra pengembangannya di Kota Bitung, hal ini berimplikasi kepada dukungan dari daerah-daerah berbasis perikanan lainnya di kawasan ini untuk bersinergi secara terintegrasi guna mendukung keberhasilan industri perikanan secara kesluruhan. Dengan perkataan lain, daerah lain seperti Kabupaten Sorong dan Kota Ternate dapat mengambil peran dari sub sistem lainnya seperti mendukung dalam jumlah pasokan bahan baku (cakalang) ke lokasi sentra pengembangan melalui industri penangkapan di daerah-daerah tersebut.

Di samping itu, berimplikasi pula kepada pentingnya konsistensi implementasi kebijakan pengembangan industri pengolahan perikanan di KTI dalam memperhatikan faktor-faktor yang terkait erat dengan prioritasi pemilihan komoditas cakalang sebagai bahan baku utama yang akan dikembangkan dan Kota Bitung sebagai lokasi sentra pengembangannya. Terkait dengan prioritasi pemilihan komoitas cakalang sebagai bahan baku utama, maka implementasi kebijakan tersebut tetap memperhatikan faktor ketersediaan sarana penangkapan, potensi pasar, tingkat keuntungan usaha dan biaya penangkapan ikan sebagai penentu arah pengembangannya ke depan. Demikian pula implementasi kebijakan terkait dengan prioritas utama lokasi sentra pengembangan, arah pengembangan ke depan harus memperhatikan secara serius untuk mewujudkan faktor-faktor potensi usaha indutri pengolahan, potensi jaringan informasi, potensi transportasi, aksessibilitas ke pusat pertumbuhan dan potensi pasar ikan agar dapat efektif mendorong keberhasilan pengembangan industri tersebut dengan lokasi sentra di Kota Bitung.

\section{DAFTAR PUSTAKA}

Aziz, M.A, 2003. Strategi Operasional Permodalan Investasi dan Perdagangan Agroindustri dalam Permodalan Agroindustri. PPA-CIDES-UQ, Jakarta.

Bailey, C, F. Marahudin, 1997. Fish Marketing and Distribution. In Bailey, C, Dwiponggo, F. Marahudin (eds.).: Indonesian Marine Capture Fisheries. ICLARM Manila. Philippine.

Darwis A, Djatmiko, A.B., Eriyatno, Sumaatmadja, D. Toyib, A.T., Hardjo, S. Wijandi,S., Kuswandi, Said,
E.G.1983. Pengembangan Agro Industri di Indonesia. IPB, Bogor

Direktorat Jenderal Perikanan Tangkap, 2001. Statistik Perikanan Tangkap. Direktorat Jenderal Perikanan Tangkap. Jakarta.

Dinau, A. 2003. Aspek Pembiayaan Bisnis Usaha Perikanan. Makalah disampaikan dalam Seminar Nasional Prospek Bisnis Kelautan dan Perikanan di Era Perdagangan Bebas.Bengkalis 15 Januari 2003 : 8 pp.

Hartarto. 1993. Investasi dan Perdagangan dalam Agroindustri lkan Tuna dan Udang. PPA-CIDES-UQ. Jakarta.

Heruwati, E.S. 2003. Pengembangan Produk Pascapanen Sebagai Salah Satu Strategi dalam Akselerasi Pembangunan Perikanan. Menggapai Cita-Cita Luhur Perikanan Sebagai Sektor Andalan Nasional. Ikatan Sarjana Perikanan Indonesia (ISPIKANI) bekerja sama dengan Drepartemen Kelautan dan Perikanan (DKP). Jakarta. p. 270284.

Kamaludin, R. 1987. Ekonomi Transportasi. Ghalia Indonesia, Jakarta

Ma'arif, M.S. 1993. Analisis Strategi Aktor: Suatu Kajian dalam Pengembangan Agroindustri Berbasis Teknologi Inovatif. Laboratorium Teknik dan Manajemen Industri. Fakultas Teknologi Pertanian. IPB. Bogor.

Marimin. 2004. Teknik dan Aplikasi Pengambilan Keputusan Kriteria Majemuk. Grasindo, Jakarta. 197 pp.

Marimin dan Sutiyono, A. 2002. Teoridan Aplikasi Sistem dalam Teknologi Manajerial. IPB Press. Bogor.

Manning, W.A. 1984. Decision Making. How a Microcomputer Aids the Process Interface. Portland State University.

Manurung, V. T. Djauhari, A, Winarno, B. dan Srigio, A. 1997. PIR Sebagai Suatu Model Pengembangan Perikanan Tuna Cakalang: Kasus di Kabupaten Sorong, Irian Jaya. Prosiding Agribisnis. Dinamika Sumberdaya dan Pengembangan Sistem Usaha Pertanian. Buku II. Pusat Penelitian Sosial Ekonomi Pertanian, Deptan. Bogor. p. 391-416.

Muspitawati, H. 2002. Kajian Strategi Peningkatan Kualitas Produk Industri Sayuran Segar (Studi Kasus diPT. Saung Mirwan, Ciawi Bogor). Skripsi. Fakultas Pertanian, IPB. Bogor.

Putro, S. 2003. Penahanan dan Penolakan Ekspor Hasil Perikanan di Uni Eropa. Menggapai Cita-Cita Luhur Perikanan Sebagai Sektor Andalan Nasional. Ikatan Sarjana Perikanan Indonesia (ISPIKANI) bekerja sama dengan Drepartemen Kelautan dan Perikanan (DKP). Jakarta. p. 285-294.

Porter, M. 1993. Strategi Bersaing : Teknik Menganalisa Industri Bersaing (Terjemahan). Erlangga, Jakarta.

Sarjono, Reswati, E., Susanto, K. 1994. Kelembagaan dan Eksternalitas Perusahaan Inti Rakyat Sistem Parsial dalam Penangkapan Cakalang di Sulawesi Tenggara. Jurnal Penelitian Perikanan Laut, No. 85, 1994. Balai Penelitian Perikanan laut. Badan 
Penelitian dan Pengembangan Perikanan. Jakarta. p. $40-47$.

Simanjuntak, S. 2001. Platform Riset Ekonomi Sumberdaya Perikanan. Forum Riset Sosial Ekonomi Kelautan dan Perikanan. Pusat Riset Pengolahan Produk dan Sosial Ekonomi Kelautan dan Perikanan. Badan Riset Kelautan dan Perikanan, DKP. Jakarta.

Simorangkir, S, 2003. Status perikanan Tuna Nasional. Lokakarya pengkajian stok Sumberdaya Ikan Nasional, Jakarta 25 Maret 2003. Dilaksanakan atas Kerjasama Masyarakat perikanan Nusantara (MPN), Ditjen Perikanan laut- Ikatan Sarjana Perikanan Indonesia (IPSIKANI).

Sutiyono, A. 2000. Model Sistem Manajemn Ahli Perencanaan Investasi Produk Agroindustri Komoditas Umbi-umbian. Skripsi. Fakultas Teknologi Pertanian IPB. Bogor.

Sujarto, D. 1987. Pilihan Startegi Suatu Model Pengambilan Keputusan dalam Perencanaan.
Departemen Planologi, FTSP. Insititut Teknologi Bandung. Bandung.

Takhasima, F. 1995. Keynote Address: Strategy for the Improvement of the Quality of Fisheries Product in Asia. In: Subiyanto and E. Watanabe (eds.). Proceeding Fisheries Science in Tropical Area with Special Reference to Post-Harvest Subjects in $21^{\text {st }}$ Centruty. The First Seminar on Seafood Sci. \& Tech. In Tropical Area. In Coop. Of Doponegoro Univ. and Tokyo Univ. of Fishesries, p. 3-4.

Tim Samudra. 2005. Tim Uni Eropa Investigasi Eksportir Tuna. Samudra, Edisi Thn III, 28 Juli 2005. PT. Samudra Komunikasi Utama. Jakarta. p. 10-12.

Toding, S. 199. Analisis Dampak Perkembangan Industri Perikanan Terhadap Kelembagaan Ekonomi Lokal. Fakultas Teknik Industri, ITB. Bandung.

Wawa, J.E. 2003. Mampukah Indonesia Jadi Pemain Utama di Pasar Dunia ?. Kompas, 10 April 2003. Kompas Jakarta. 


\section{LAMPIRAN}

Lampiran 1. Hasil analisa pendapat responden pada perbandingan kriteria untuk pemilihan komoditi dalam pengembangan industri perikanan di Kawasan Timur Indonesia

Appendix 1. Result of respondent judgement analysis for comparison criteria comparison to commodity choice of fsiheries industry development in Eastern Indonesian

\begin{tabular}{|c|c|c|c|c|c|c|c|c|c|c|c|c|}
\hline $\begin{array}{l}\text { Responden/ } \\
\text { Respondent }\end{array}$ & 1 & & 2 & & 3 & & 4 & & 5 & & 6 & \\
\hline $\begin{array}{c}\text { Kritrial } \\
\text { Criterions }\end{array}$ & $\begin{array}{l}\text { Bobot/ } \\
\text { Weight }\end{array}$ & $\operatorname{Pr}$ & $\begin{array}{l}\text { Bobot } \\
\text { Weight }\end{array}$ & Pr & $\begin{array}{l}\text { Bobot/ } \\
\text { Weight }\end{array}$ & $\mathbf{P r}$ & $\begin{array}{l}\text { Bobot/ } \\
\text { Weight }\end{array}$ & Pr & $\begin{array}{l}\text { Bobot/ } \\
\text { Weight }\end{array}$ & Pr & $\begin{array}{l}\text { Bobotl } \\
\text { Weight }\end{array}$ & Pr \\
\hline BB & 0,157 & 3 & 0,089 & 8 & 0,064 & 7 & 0,081 & 7 & 0.098 & 5 & 0,072 & 7 \\
\hline TK & 0,121 & 5 & 0,135 & 4 & 0,091 & 5 & 0,138 & 3 & 0,053 & 6 & 0,087 & 6 \\
\hline PP & 0,213 & 1 & 0,143 & 2 & 0,178 & 2 & 0,216 & 1 & 0,176 & 3 & 0,174 & 2 \\
\hline $\mathrm{KB}$ & 0,047 & 8 & 0,073 & 9 & 0,049 & 8 & 0,062 & 8 & 0,020 & 9 & 0,049 & 8 \\
\hline$T M$ & 0,041 & 9 & 0,114 & 5 & 0,033 & 9 & 0,049 & 9 & 0,046 & 7 & 0,036 & 9 \\
\hline SP & 0,134 & 4 & 0,172 & 1 & 0,236 & 1 & 0,167 & 2 & 0,184 & 2 & 0,273 & 1 \\
\hline BK & 0,079 & 7 & 0,136 & 3 & 0,125 & 4 & 0,107 & 5 & 0,139 & 4 & 0,132 & 4 \\
\hline $\mathrm{KP}$ & 0,093 & 6 & 0,106 & 7 & 0,087 & 6 & 0,089 & 6 & 0,037 & 8 & 0,091 & 5 \\
\hline TU & 0,189 & 2 & 0,110 & 6 & 0,134 & 3 & 0,131 & 4 & 0,282 & 1 & 0,146 & 3 \\
\hline
\end{tabular}

Keterangan/Remaks:

$\mathrm{BB}=$ Ketersediaan bahan baku/Availability raw matterial

$\mathrm{TK}=$ Ketersediaan tenaga kerja/Availability labors stock

PP = Potensi pasar komoditi/Market potential

$\mathrm{KB}=$ Keanekaragaman olahan/Diversity of fish processing product

$\mathrm{TM}$ = Kemudahaan penanganan pasca panen/Ease of post harvest

$\mathrm{SP}=$ Ketersediaan sarana produksi/Availability of product input

$\mathrm{BK}=$ Biaya penangkapan/Cost of fishing

KP = Dukungan kebijakan pemerintah/Government policy support

$\mathrm{TU}=$ Tingkat keuntungan/Level of profit

$\mathrm{Pr} \quad=$ Prioritas/Priority 
Lampiran 2. Hasil analisıs pendapat respoden pada perbandingan kriteria untuk pemilihan lokasi sentra dalam pengembangan industri perikanan di Kawasan Timur Indonesia

Appendix 2. Result of respondent judgement analysis to comparison criteria for central location choice in fisheries industry development in Eastern Indonesian

\begin{tabular}{ccccccccccccc}
\hline $\begin{array}{c}\text { Responden/ } \\
\text { Respondent }\end{array}$ & $\mathbf{1}$ & $\mathbf{2}$ & $\mathbf{3}$ & $\mathbf{4}$ & $\mathbf{5}$ & $\mathbf{6}$ \\
\hline $\begin{array}{c}\text { Kritrial } \\
\text { Criterions }\end{array}$ & $\begin{array}{c}\text { Bobot/ } \\
\text { Weight }\end{array}$ & $\mathbf{P r} \begin{array}{c}\text { Bobot/ } \\
\text { Weight }\end{array}$ & $\mathbf{P r}$ & $\begin{array}{l}\text { Bobot/ } \\
\text { Weight }\end{array}$ & $\mathbf{P r}$ & $\begin{array}{c}\text { Bobot/ } \\
\text { Weight }\end{array}$ & Pr & $\begin{array}{c}\text { Bobot/ } \\
\text { Weight }\end{array}$ & Pr & $\begin{array}{c}\text { Bobot/ } \\
\text { Weight }\end{array}$ & Pr \\
\hline PB & 0,035 & 8 & 0,037 & 8 & 0,052 & 7 & 0,051 & 7 & 0,148 & 4 & 0,069 & 6 \\
PU & 0,098 & 5 & 0,116 & 4 & 0,196 & 2 & 0,234 & 1 & 0,274 & 1 & 0,180 & 2 \\
PP & 0,116 & 4 & 0,079 & 5 & 0,131 & 5 & 0,173 & 4 & 0,162 & 3 & 0,171 & 3 \\
TK & 0,048 & 6 & 0,061 & 6 & 0,066 & 6 & 0,072 & 6 & 0,052 & 7 & 0,056 & 7 \\
PT & 0,320 & 1 & 0,241 & 1 & 0,247 & 1 & 0,198 & 2 & 0,221 & 2 & 0,196 & 1 \\
DM & 0,041 & 7 & 0,054 & 7 & 0,045 & 8 & 0,032 & 8 & 0,063 & 6 & 0,041 & 8 \\
AK & 0,238 & 2 & 0,197 & 3 & 0,143 & 4 & 0,104 & 5 & 0,049 & 8 & 0,164 & 4 \\
JI & 0,121 & 3 & 0,234 & 2 & 0,164 & 3 & 0,169 & 3 & 0,090 & 5 & 0,138 & 5 \\
\hline
\end{tabular}

Keterangan/Remaks:

$\mathrm{PB}=$ Potensi bahan baku/Raw matterials potential

$\mathrm{PU}=$ Potensi usaha industri pengolahan/Processing industri bussines potential

$\mathrm{PP}=$ Potensi pasar komoditi/Commodity market Potential

$\mathrm{TK}=$ Potensi tenaga kerja/Labor potential

PT = Potensi transportasi/Transportation potential

$\mathrm{DM}$ = Dukungan masyarakat setempat/Support from local society

AK = Aksesibilitas ke pusat pertumbuhan/Accessibility to the centre of growth

$\mathrm{Jl}=$ Jaringan informasi//nformation network

$\operatorname{Pr} \quad=$ Prioritas/Priority 
